\title{
PROMOSI DAERAH DAN E-MARKETING PARIWISATA HALAL TERHADAP KEPUTUSAN BERKUNJUNG WISATAWAN DI YOGYAKARTA
}

\author{
Raja Ela Safira \\ Universitas Alma Ata, Yogyakarta, Indonesia \\ Email: raja.ella.safira@gmail.com \\ Winda Sholikah \\ Universitas Alma Ata, Yogyakarta, Indonesia \\ Email:windasholikah97@gmail.com \\ Dhidhin Noer ady Rahmanto \\ Universitas Alma Ata, Yogyakarta, Indonesia \\ Email:dhidhin@almaata.ac.id
}

\begin{abstract}
Regional Promotion and E-Marketing of Halal Tourism against Tourist Visits in Yogyakarta. This research was conducted to find out how the influence of Halal Tourism Promotion Based on E-Marketing against Tourist Visits in Yogyakarta. Promotion is an important thing that needs to be considered in attracting tourists. In this millennial era, the development of technology very fast, many activities using technology. Furthermore, the using of E-Marketing more suitable for increasing the number of tourists. This research used multiple linear regression method with moderating variables to show the influence of Halal Tourism Promotion Based on EMarketing Against Tourist Visits in Yogyakarta with data collection techniques used were questionnaires and observations. The result of this research was found that using E-Marketing can increase tourist's interest to visit halal tourism in Yogyakarta. When using regional promotions only gained 7\% and when using E-Marketing increased to $67 \%$.
\end{abstract}

Keywords: E-Marketing; Halal Tourism; Tourism Promotion.

Abstrak. Promosi Daerah dan E-Marketing Pariwisata Halal Terhadap Keputusan Berkunjung Wisatawan di Yogyakarta. Penelitian ini dilakukan untuk mengetahui bagaimana pengaruh Promosi Pariwisata Halal Berbasis E-Marketing Terhadap Keputusan Berkunjung Wisatawan di Yogyakarta. Promosi merupakan hal penting yang perlu dilakukan dan diperhatikan dalam menarik minat wisatawan. Di era milenial ini teknologi sangat berkembang dengan pesat, sehingga banyak aktivitas yang dilakukan menggunakan teknologi. Dengan demikian penggunaan E-Marketing dinilai cocok untuk meningkatkan wisatawan. Metode pengujian adalah dengan menggunakan metode regresi linier berganda dengan variabel moderating untuk 
Islamiconomic: Jurnal Ekonomi Islam Vol.10 No.1 Januari - Juni 2019

menunjukkan hasil dari penelitian pengaruh Promosi Pariwisata Halal Berbasis EMarketing Terhadap Keputusan Berkunjung Wisatawan di Yogyakarta. Teknik pengumpulan data yang digunakan adalah menggunakan kuesioner dan observasi. Dari hasil penelitian ini ditemukan bahwa penggunaan E-Marketing dapat meningkatkan minat wisatawan untuk berkunjung ke pariwisata halal di Yogyakarta. Pada awalnya ketika menggunakan promosi daerah hanya memperoleh sebesar 7\% dan ketika menggunakian E-Marketing meningkat menjadi 67\%.

Kata Kunci: E-Marketing; Pariwisata Halal; Promosi Pariwisata. 


\section{PENDAHULUAN}

Berkembangnya cara mempromosikan suatu jasa dengan teknologi pada Era millenial ini, telah berhasil mempengaruhi berbagai macam aspek kehidupan. Kecepatan dan ketepatan dalam mengakses sebuah informasi dapat dilakukan melalui hanya dengan mengoperasikan sebuah gadget, komunikasi juga seolah menjadi instrumen pendukung eksistensi globalisasi dalam segala bidang. Hal ini tentu berdampak pada gaya hidup seseorang di Era komputer ini. Gaya hidup yang dulunya hanya berpusat kepada gaya berbusana ataupun berkendara saat ini juga sudah berkembang khususnya dalam bidang pariwisata salah satu bidang pariwisata halal yang banyak diperbicarakan adalah pariwisata halal. (Omi Sarah, 2018)

Wisata halal merupakan salah satu bentuk wisata berbasiskan budaya yang menempatkan nilai - nilai dan norma Syariat Islam sebagai pedoman dasarnya. Wisata halal memiliki ragam yang lebih luas lagi. Tak hanya berhenti di wisata ke lokasi - lokasi religi saja, namun juga merambah ke lokasi - lokasi umum dengan tetap menjaga aturan sebagai Muslim serta memberikan layanan serta kemudahan fasilitas bagi para wisatawan muslim untuk dapat beribadah di sela - sela waktu kunjungan mereka ke destinasi - destinasi wisata (Nugraha, Marta, 2018).

Populasi umat muslim secara keseluruhan dikategorikan sangat besar dan semakin bertambah. Dulu diperkirakan 1,8 miliar pada tahun 2005 (24,1\% dari populasi dunia), proporsi yang diprediksi kan akan meningkat menjadi 31,1\% dengan 3 miliar penduduk pada tahun 2060 Salman Yousaf, fan xiucheng (2017). Pada tahun 2013 lalu, Kementrian Pariwisata dan Ekonomi Kreatif dalam kegiatan Indonesia Halal Expo (Indhex) 2013 dan Global Halal Forum meluncurkan produk baru dalam perindustrian pariwisata yaitu pariwisata halal (Halal Tourism). Peluncuran Halal Tourism ini dilandasi dengan mengingat Indonesia merupakan negara dengan mayoritas penduduknya beragama Islam terbesar di dunia sebesar 207.176.162 (BPS, 2010). Artinya dengan penduduk yang mayoritasnya agama Islam, sudah seharusnya Indonesia bisa menjadi negara yang sukses dalam mengembangkan pariwisata dengan konsep Syariah (Halal Tourism). 
Wisata halal hadir sebagai konsep baru yang ditawarkan di dalam industry pariwisata, tentunya wisata yang berbasis Syariah ini masih sangat memerlukan pengembangan yang lebih lanjut dan diikuti dengan pemahaman yang komprehensif yang berhubungan dengan kolaborasi nilai- nilai ke Islaman yang dimasukkan ke dalam kegiatan pariwisata. Hal ini disebabkan adanya penilaian terhadap konsep pariwsata halal ini di Indonesia masih sangat tertinggal jauh jika dibandingkan dengan negara negara seperti Thailand dan juga Malaysia. Jika dilihat dari jumlah penduduk di Indonesia, penduduk muslim merupakan populasi terbanyak dan ini menggambarkan bahwa wisatawan muslim menduduki kelas teratas dalam industry pariwisata.

Indonesia dengan jumlah penduduk muslim terbesar di dunia, konsep wisata halal merupakan solusi dan jawaban akan besarnya untapped market yang belum tersentuh dengan maksimal. Dengan potensi penduduk muslim terbesar di dunia maka Indonesia merupakan pangsa pasar industri wisata Halal terbesar dan sudah seharusnya disadari oleh pemerhati bisnis pariwisata di Indonesia hal ini dikarenakan pengembangan wisata Halal yang berkelanjutan akan dapat memberikan kontribusi pengembangan ekonomi yang cukup signifikan bagi seluruh pelaku yang di dalamnya.

Informasi secara online merupakan sarana dari strategi marketing yang dinilai memiliki tingkat pengaruh yang cukup besar dalam mempengaruhi tingkat pengambilan keputusan oleh konsumen (pemakaian jasa pariwisata) dengan ini kehadiran E-marketing diharapkan mampu memberikan ruang yang tepat bagi pengembangan konsep pariwisata halal (Halal Tourism) dengan cara memberikan informasi yang efektif dan efisien bagi para calon konsumen. E-marketing atau yang biasa dikenal dengan pemasaran berbasis elektronik yang bersandarkan pada penerapan prinsip-prinsip pemasaran dan teknik menggunakan media elektronik secara khususnya adalah internet.

Dengan definisi itu $E$ - marketing mencakup semua kegiatan dalam bisnis yang menggunakan web atau internet dengan tujuan untuk menarik calon konsumen baru atau lama dengan mempertahankan citra dari bisnis serta diiringi dengan pengembangan identitas dari merek/brand bisnis tersebut. 
Pengguna internet sudah mencapai lebih dari $50 \%$ atau setara dengan 143 juta orang sudah terhubung dengan jaringan internet sepanjang tahun 2017 (Asosiasi Penyelenggara Jasa Internet Indonesia), dari data tersebut dapat diketahui mayoritas pengguna internet sebanyak $72,41 \%$ masih dikalangan masyarakat urban. Pengguna internet memanfaatkan internet bukan sekedar untuk berkomunikasi tetapi juga untuk melakukan transaksi jual barang, berbisnis dan berkarya. Berdasarkan letak geografisnya, masyarakat Jawa menempati posisi pertama yang terpapar internet sebesar 57,70\%, posisi selanjutkan ditempati oleh Sumatera sebesar 19,09\%, Kalimantan sebesar 7,97\%, Sulawesi sebesar 6,73\%, Bali - Nusa 5,63\%, dam Maluku - Papua sebesar 2,49\% (Fatimah,2010)

Pemasaran melalui internet sangat memungkinkan untuk menjangkau konsumen, khususnya dalam pengembangan pariwasata halal ini sangat membantu untuk mempromosikan pariwisata suatu daerah kepada calon pengguna jasa pariwisata yang ada diluar daerah tersebut bahkan bisa menjangkau pangsa pasar internasional. Oleh karena itu diperlukan penelitian yang lebih mendalam lagi terkait dengan pengaruh promosi berbasis E-Marketing dalam menarik minat berkunjung wisatawan di destinasi wisata - wisata yang ada di Yogyakrta serta mendukung perkembangan pariwisata halal di Yogyakarta.

\section{PENGERTIAN PARIWISATA HALAL}

Organisasi Konferensi Islam (OKI) sudah melakukan pengkajian yang mendalam terkait pariwisata halal dan hasil dari kajian tersebut dibahas dalam pertemuan Word Tourism Organization. Pariwisata halal merupakan suatu bentuk permintaan wisata yang didasarkan pada gaya hidup wisatawan muslim selama menjalani kegiatan liburan. Selain dari itu pariwisata halal merupakan bentuk pariwisata yang bersifat fleksibel, rasional, sederhana namun juga seimbang. Pariwisata halal memiliki tujuan agar wisatawan termotivasi untuk mendapatkan kebahagiaan dan tentunya mendapatkan berkat dari Allah (Munirah, 2012). 
Karakteristik Pariwisata Halal

Menurut Chookaew (2015), terdapat 8 faktor standar dalam mengukur pariwisata halal bisa dilihat dari sisi administrasi dan tata pengelolaannya untuk semua wisatawan yang mana hal tersebut dapat menciptakan karakteristik tersendiri, yaitu:

a) Pelayanan kepada wisatawan harus sesuai dengan prinsip - prinsip muslim secara keseluruhan.

b) Pemandu dan staf harus memiliki disiplin dan juga harus menghormati prinsip prinsip Islam.

c) Mengatur semua kegiatan agar tidak bertentangan dengan prinsip - prinsip Islam.

d) Bangunan harus sesuai dengan aturan prinsip - prinsip Islam.

e) Restoran harus mengikuti standar internasional terkait pelayanan halal.

f) Layanan transportasi harus memiliki keamanan sistem proteksi.

g) Ada tempat - tempat yang disediakan untuk wisatawan muslim ketika ingin melakukan kegiatan kegamaan.

h) Bepergian ke tempat- tempat yang tidak dilarang atau bertentangan dalam prinsip - prinsip Islam.

Dari penjabaran 8 poin karakteristik diatas dapat disimpulkan terdapat 4 aspek penting yang harus diperhatikan untuk menunjang perkembangan sektor pariwisata halal di Yogyakarta, diantaranya marketing, pelayanan, sarana dan prasarana. Menurut Sofyan (2012:33), bahwa definisi pariwisata halal lebih luas dibandingkan dengan hanya sekedar wisata religi yang didasarkan dengan nilai - nilai halal dalam Islam. Word Tourism Organization (WTO), menganjurkan bahwa konsumen wisata halal tidak hanya umat muslim saja tetapi juga non-Muslim yang ingin menikmati kearifan lokal suatu daerah pariwisata. 
Sofyan selaku pemilik jaringan hotel menjelaskan, kriteria umum pariwisata halal adalah:

a) Memiliki orientasi terhadap kemaslahatan umum.

b) Memiliki orientasi berupa pencerahan, penyegaran, dan juga ketenangan.

c) Menghindarkan dari kemusyrikan.

d) Keempat, bebas dari maksiat.

e) Menjaga keamanan dan juga kenyamanan.

f) Menjaga kelestraian lingkungan.

g) Menghormati nilai - nilai budaya dan kearifan masyarakat setempat.

\section{E-MARKETING}

Menurut Kotler saluran online (E-marketing) adalah saluran yang dapat dijangkau seseorang melalui komputer dan modem. Modem menghubungkan computer dengan jalur telepon sehingga komputer menjangkau beragam layanan informasi secara online (Kotler,2008). Sedangkan Brenda Kienan mengatakan bahwa E-marketing adalah menjual produknya kepada calon konsumen dalam bentuk online. Secara sederhananya E-marketing adalah membuat, mengelola, dan meluaskan hubungan komersial secara online (Kienan, 2001).

Menurut Chen-Ling, \&Lie, dalam Journal of American Academy of Business (2006:296), E-marketing merupakan proses memasarkan produk serta layanan kepada pelanggan dengan memanfaatkan media web. Pengguna internet market dapat dengan mudahnya untuk mengakses sebuah informasi dimana saja dengan menggunakan computer yang sudah terhubung dengan jaringan internet.

Online consumer dapat didefinisikan sebagai konsumen yang mencari informasi atau bahkan melakukan pembelian melalui internet. Menurut Hoffman \& Novak (1996) online consumer memiliki motivasi berbeda dalam memanfaatkan informasi melalui internet. Sebagai konsumen memanfaatkan internet untuk mencari produk atau jasa, ataupun hanya untuk navigasi (pandu arah) informasi dan pengalaman. 
Menurut Peter and Olson (2000:108) terdapat beberapa faktor yang dapat mempengaruhi perhatian konsumen (consumer so attention) terhadap informasi pemasaran yaitu:

a) Kondisi afektif konsumen, dapat mempengaruhi perhatian terhadap informasi pemasaran (iklan). Kondisi afektif ini misalnya moods (bosan atau relax), emosi (senang atau marah), perasaan (puas atau frustasi). Konsumen yang dalam keadaan tidak baik (bad mood) maka akan melihat aspek yang ada dilingkunganya secara negatif dan begitu pula sebaliknya.

b) Tingkat keterlibatan konsumen terhadap informasi didalam iklan, keterlibatan (involvement) sifatnya dapat memotivasi konsumen dan menuntun kepada focal attention dan pemahaman (comprehension). Misalnya orang yang menyukai fotografi akan lebih memberi perhatian terhadap iklan mengenai produk foto.

c) Apakah informasi tersebut terlihat menonjol dalam lingkungan konsumen, keadaan lingkungan dapat menarik perhatian konsumen. Misalnya perusahaan membuat label yang penuh warna untuk perhatian konsumen, aroma kue yang sengaja diciptakan agar pengunjung mall dapat mencium aroma kue dan menarik perhatian wisatawan. Bruner dan Kumar (2000) menyatakan bahwa terdapat layered effect antara tingkat perhatian konsumen, sikap terhadap iklan, dan dampak yang muncul dari sebuah iklan banner internet. Contact and attention terhadap sebuah iklan dapat mempengaruhi sikap terjadap iklan tersebut, dan juga mempengaruhi perilaku pembelian wisatawan.

\section{PROMOSI}

Promosi merupakan aspek penting yang perlu diperhatikan dan dilakukan dalam menarik minat wisatawan. Promosi bertujuan memfasilitasi dalam bentuk komunikasi antara orang yang menawarkan produk/jasanya kepada masyarakat. Karena tolak ukur sebuah keberhasilan dalam menarik minat wisatawan dilihat dari tingkat pengunaan dan kunjungan wisatawan serta pemanfaatan informasi oleh 
Raja Ela Safitri, dkk.: Promosi Daerah dan E-Marketing...

wisatawan. Hal yang penting yang harus digarisbawahi adalah dukungan dari pihak manajemen, karena promosi sudah seharusnya masuk anggaran terbesar dalam memasarkan produk/jasanya.

Promosi daerah merupakan suatu hal yang memutuhkan beberapa perencanaan khusus, karena pada dasarnya promosi daerah sangat berbeda dengan jenis promosi produk/jasa lain yang dipromosikan. Untuk kontek daerah Yogyakarta saat ini promosi daerah sangat diperlukan karena daerah Yogyakarta memiliki banyak tempat tujuan untuk berpariwisata. Jika promosi daerah Yogyakarta sudah dirancang dengan baik dan benar akan memberikan peluang kontribusi pendapatan daerah, serta mendorong proses dari multiplier perkembangan ekonomi lokalitas di sekitaran daerah tujuan pariwisata. Tujuan dari promosi yang dilakukan oleh daerah dapat dikelompokkan ke dalam beberapa tujuan, yaitu:

a) Mempromosikan lokalitas wisata sebagai tujuan wisata yang menarik dan dapat menguntungkan wisatawan

b) Meningkatkan citra tempat wisata daerah di kota Yogyakarta dalam pasar domestik bahkan merambah ke pasar internasional

c) Menginformasikan ilmu pengetahuan tentang produk-produk wisata halal yang sudah kembangkan oleh daerah

\section{METODOLOGI PENELITIAN}

Langkah pertama, dalam penelitian ini dimulai dengan melakukan observasi awal terkait Halal Tourism dan promosi berbasis E-marketting yang bisa dimulai dari menganalisis beberapa pengunjung pariwisata halal yang menggunakan gadget. Selanjutnya menganalisis beberapa media yang digunakan untuk promosi daerah seperti brosur, iklan pemerintah dalam halaman web untuk menentukan bagaimana pengaruh promosi yang digunakan terhadap keputusan berkunjung di Yogyakarta. Konten Jogja Istimewa dikembangkan oleh Pemerintah DIY yang dirancang agar sesuai dengan tagline kota Jogja. Aplikasi ini dinilai membantu wisatawan yang buta akan pengetahuan kota jogja sehingga mempermudah mereka untuk menemukan destinasi wisata. 
Mengingat kehadiran Halal Tourism ini diringi dengan beberapa pendamping seperti makanan halal, fasilitas serta layanan halal (hotel, spa, restaurant dan biro perjalanan wisata) dinilai sangat penting bagi wisatawan muslim. Peneliti menganalisis sejauh mana masalah ini sudah ditangani secara memadai di situs web pemerintah dengan melakukan beberapa bentuk promosi berbasis digital yang secara garis besarnya memberikan beberapa informasi kepada wisatawan. Studi difokuskan pada:

1. Mengembangkan kerangka pemasaran dalam bentuk promosi sebagai salah satu strategi mengenalkan pariwsata halal di internet

2. Menganalisis jangkauan dan keberagaman situs-situs web dalam melakukan promosi digital

3. Model analisis lima konten (Neuman, 2003) yang akan diterapkan dalam menguji validitas analisis konten dengan menggandeng beberapa ahli konten. Pada tahap pertama analisis sebuah konten didasarkan dengan tujuan dan sasaran dari penelitian yang sudah ditentukan.

Langkah kedua, yang akan dilakukan adalah observasi dan penyebaran kuisioner kepada wisatawan. Survey kepada wisatawan yang sedang berada di beberapa wilayah wisata yang ada di Yogyakarta.

1. Teknik Pengumpulan Data

Teknik pengumpulan data dalam penelitian ini adalah observasi, penyebaran kuisioner serta dokumentasi.

\section{a. Observasi}

Teknik observasi yang dipilih oleh peneliti adalah yang memiliki keterkaitan dengan latar belakang fokus masalah. Dalam penelitian ini dimana pengamat bertindak sebagai partisipan. Subjek penelitian menggunakan teknik Purposive Sampling yakni pengambilan sampel yang bertujuan untuk memenuhi kepentingan penelitian. Sehingga jumlah responden yang diambil sebanyak 85 wisatawan. 
b. Teknik Dokumentasi

Merupakan teknik pengumpulan data dari non insani, sumber ini terdiri dari beberapa dokumen dan rekaman yang mendukung proses pengumpulan data dalam penelitian ini.

Langkah ketiga, setelah semua data sudah terkumpul, maka langkah selanjutnya adalah menganalisa dan mengolah data yang ada. Yang dimaksud dengan menganalisa data merupakan proses mencari dan menyusun secara sistematis data yang diperoleh dari hasil catatan lapangan, dan dokumentasi, dengan cara mengorganisasikan data ke dalam beberapa kategori, menjabarkan ke dalam unit unit, melakukan sintesa, menyusunnya ke dalam pola, memilih mana yang penting untuk dipelajari, serta membuat kesimpulan sehingga mudah untuk dimengerti oleh peneliti maupun orang lain.

\section{PEMBAHASAN}

Dalam pembahasan sebelumnya sudah dipaparkan tujuan dari penelitian ini untuk mengetahui seberapa besar pengaruh hubungan antara promosi daerah pariwisata halal dan E-marketing terhadap keputusan berkunjung wisatawan di kota Yogyakarta. Untuk mendapatkan jawaban atas pertanyaan tersebut, maka perlu dilakukan pengumpulan informasi dan data dengan metode survei melalui penyebaran kuisioner kepada wisatawan yang pernah berkunjung ke wisata Syariah maupun yang belum pernah berkunjung ke pariwisata Syariah di kota Yogyakarta.

Setelah informasi yang diperoleh melalui kuisioner maka dapat diketahui bagaimana keyakinan wisatawan terhadap informasi terkait produk/jasa yang berkaitan dengan pariwisata halal melalui sosial media sehingga bisa mempengaruhi keputusan untuk berkunjung ke wisata Syariah di kota Yogyakarta. Dengan cara ini konsumen sebagai responden dalam penelitian ini bisa melihat indikator apa saja yang berhubungan dengan wisata Syariah yang ada di kota Yogyakarta. 
Kuisioner yang digunakan untuk memperoleh informasi terdiri dari 85 responden sejumlah 23 instrumen. Dalam lampiran kuisioner ini, responden diharuskan mencantum identitas pribadi responden. Pertanyaan dalam kuisioner dikembangkan dengan menggunakan 2 pendekatan. Pertama, pertanyaan yang sifatnya terbuka, pertanyaan ini diharapkan mampu memperoleh data seperti umur, jenis kelamin, Pendidikan terakhir, dan rata - rata pendapatan dalam jangka waktu 1 tahun. Kedua, pertanyaan yang sifatnya lebih tertutup. Pertanyaan ini merupakan bentuk respon terkait promosi berbasis E-marketing terhadap keputusan berkunjung wisatawan. Respon dari responden ditunjukkan dengan alternative jawaban dan skor jawaban yang telah ditetapkan oleh peneliti.

Sebagai proses Analisa awal, dari hasil uji validitas dengan menggunakan bantuan SPSS 22, Dengan demikian variabel x1 dengan 12 pernyataan, x2 4 pernyataan, dan y1 9 pernyataan yang diuji, maka diperoleh nilai $r$ hitung untuk masing-masing pernyataan lebih besar dari nilai $r$ tabel. Namun ada beberapa Pernyataan x1 yang tidak lolos dalam nilai validitas pada pernyataan nomor 9, 11,12 dan Pernyataan y1 yang tidak lolos dalam nilai validitas pada pernyataan nomor 7 dan 9. Maka pada variabel yang mempunyai nilai di bawah standart dalam penelitian inidi eliminasi guna menjaga ke akuratan data yang di pakai. Output olahan SPSS bisa dilihat dalam lampiran penelitian.

Uji reliabilitas dilakukan pada 3 variabel yang di uji yaitu promosi daerah dan Emarketing terhadap keputusan berkunjung wisatawan di kota Yogyakarta dapat dilihat pada output spss terlampirkan. Dari output SPSS dapat dijelaskan bahwa nilai Aplha untuk semua item telah lolos uji reliabilitas. Dari hasil penelitian diperoleh nilai alpha untuk semua pernyataan dalam penelitian ini dapat dinyatakan reliabel/handal.

Uji normalitas dilakukan untuk mengetahui data penelitian telah berdistribusi normal ataukah tidak. Dari hasil output yang didapat dari outpus SPSS menghasilkan hasil yang menunjukkan data berdistribusi normal, karena hasil dari uji kolmogorov smirnov menyatakan nilai sebesar 0,200 yang berarti nilai di atas dari 0,05 dengan kesimpulan data penelitian berdistribusi normal. 


\section{Analisis Regresi Linier Pengaruh Promosi daerah Terhadap Keputusan Berkunjung Wisatawan di Yogyakarta}

Model regresi pertama dalam penelitian ini bertujuan untuk menganalisis seberapa besar pengaruh variabel Promosi daerah terhadap Keputusan Berkunjung Wisatawan. Berikut adalah hasil analisis linier sederhana dengan menggunakan SPSS 22.

Tabel 1 Hasil Uji Linier Berganda

Pengaruh Promosi Daerah Terhadap Keputusan Berkunjung

\begin{tabular}{lcccc}
\hline Variabel & Nilai Beta & Sign Uji t & Hasil Uji R & Sign Uji F \\
\hline Promosi daerah & 0,003 & 0,976 & $0,03(3 \%)$ & 0,976
\end{tabular}

Dependent Variable: Keputusan Berkunjung

Dari hasil analisis dengan program SPSS versi 22 tersebut, maka dapat diketahui persamaan regresi dari model pertama dalam penelitian ini. Adapun persamaan regresi linier yang terbentuk adalah:

$$
\mathrm{Y}=\mathrm{a}+0,003 \text { Promosi }
$$

\section{Analisis Regresi Linier Pengaruh Promosi Berbasis E-marketing terhadap Keputusan Berkunjung Wisatawan Sebagai Moderating}

Model regresi kedua dalam penelitian ini bertujuan untuk meningkatkan keputusan berkunjung wisatawan. Sedangkan variabel yang lain adalah tetap (konstan), maka keputusan berkunjung wisatawan akan mengalami peningkatan. menganalisis seberapa pengaruh variabel Promosi daerah Berbasis E-marketing terhadap Keputusan Berkunjung Wisatawan. Berikut adalah hasil analisis linier sederhana dengan menggunakan SPSS versi 22: 
Tabel 2 Analisis Regresi Linier Berganda

Pengaruh Promosi Berbasis E-marketing Terhadap Keputusan Berkunjung

\begin{tabular}{lcccc}
\hline Variabel & Nilai beta & Sign Uji t & Hasil Uji R & Sign Uji F \\
\hline Promosi daerah & $-0,178$ & 0.032 & $0,698(69 \%)$ & 0,00 \\
Promosi E-Marketing & 0,721 & 0,000 & & \\
& & & & \\
\hline
\end{tabular}

Dependent Variable: Keputusan Berkunjung

Dari hasil analisis dengan program SPSS versi 22 tersebut, maka dapat diketahui persamaan regresi dari penelitian ini. Adapaun persamaan regresi linier yang terbentuk adalah:

$$
\mathrm{Y}=\mathrm{a}-0,178 \text { promosi }+ \text { 0,721E-marketing }
$$

\section{Koefisien Determinasi}

Koefisien Determinasi pada intinya adalah mengukur seberapa jauh kemampuan model pada Variabel Bebas (X) dalam menerangkan Variabel Terikat (Y), (Ghozali, 2006). Dalam penelitian ini koefisien determinasi dianalisis untuk menerangkan seberapa besar pengaruh adanya variabel emarketing dalam mempengaruhi keputusan berkunjung seorang wisatawan.

Koefisien determinasi model regresi pertama dilakukan untuk mengetahui seberapa jauh atau seberapa besar variabel Promosi daerah mampu menjelaskan terhadap variabel keputusan berkunjung wisatawan, dimana ditunjukkan dengan nilai R. Untuk mengetahui seberapa besar Keputusan Berkunjung Wisatawan mampu dijelaskan oleh variabel Promosi daerah, maka berikut hasil pengujian yang dibantu dengan program SPSS versi 22 adalah: 
Tabel 3 Hasil Uji Koefisien Determinasi

Pengaruh Promosi Daerah Terhadap Keputusan Berkunjung Wisatawan

\section{Model Summary}

\begin{tabular}{|l|r|r|r|r|}
\hline $\begin{array}{l}\text { Mode } \\
\mathrm{l}\end{array}$ & $\mathrm{R}$ & R Square & $\begin{array}{c}\text { Adjusted R } \\
\text { Square }\end{array}$ & $\begin{array}{r}\text { Std. Error of } \\
\text { the Estimate }\end{array}$ \\
\hline 1 &, $003^{\mathrm{a}}$ &, 000 &,- 012 & 1,78956 \\
\hline
\end{tabular}

a. Predictors: (Constant), Promosi Daerah

Dari tabel 3, angka koefisien determinasi sebesar 0,003. Hal ini berarti bahwa variabel promosi daerah memiliki peranan sebesar 3\% secara Bersama-sama untuk dapat menjelaskan atau menerangkan variabel Keputusan Berkunjung Wisatawan. Sedangkan sisanya sebesar 97\% (100\% - 3\%) dijelaskan oleh variabel lain yang mempengaruhi Keputusan Berkunjung Wisatawan.

\section{Koefisien Determinasi Pengaruh E-marketing Terhadap Keputusan Berkunjung Wisatawan}

Koefisien determinasi merupakan model regresi kedua yang digunakan untuk mengetahui seberapa besar variabel E-marketing dengan variabel kontrol Promosi Daerah dan bagaimana E-marketing bisa menjelaskan terhadap variabel keputusan berkunjung, dimana keputusannya ditunjukkan dengan nilai R . Untuk mengetahui seberapa besar Keputusan Berkunjung Wisatawan di Yogyakarta bisa dijelaskan dengan ketiga variabel yaitu E-marketing, Promosi Daerah maka berikut hasil dari pengujian yang dibantu dengan SPSS versi 22 . 
Tabel 4 Hasil Uji Koefisien Determinasi

Pengaruh Promosi Terhadap Keputusan Berkunjung wisatawan sebagai moderating

\section{Model Summary}

\begin{tabular}{|l|r|r|r|r|}
\hline Mode & \multicolumn{1}{|c|}{$\mathrm{R}$} & R Square & $\begin{array}{c}\text { Adjusted R } \\
\text { Square }\end{array}$ & $\begin{array}{r}\text { Std. Error of } \\
\text { the Estimate }\end{array}$ \\
\hline 1 &, $698^{\mathrm{a}}$ &, 487 &, 475 & 1,28928 \\
\hline
\end{tabular}

a. Predictors: (Constant), Emarketing Daerah, Promosi

Daerah

Dari tabel 4 , angka koefisien determinasi R sebesar 0,698. Hal ini berarti bahwa variabel Promosi daerah dan Emarketing memiliki peranan sebesar 69\% secara bersama-sama untuk dapat menjelaskan variabel Keputusan Berkunjung Wisatawan. Sedangkan sisanya sebesar $31 \%(100 \%$ - 69\%) dijelaskan oleh variabel lain yang mempengaruhi Keputusan Berkunjung Wisatawan.

\section{Pengujian Hipotesis}

Uji hipotesis 1 sampai dengan 3 diuji dengan mengguji parameter individual (uji statistik t) tujuan dari pengujian ini adalah untuk mengetahui besarnya pengaruh dari masing-masing variabel independent secara parsial terhadap variabel dependen. Nilai dari pengujian t dilihat dari p-value (pada kolom sig) dengan masing-maisng variabel dependen. Jika nilai p-value lebih kecil dari nilai level of signifikan 0,05. Hasil dari analisis sebagai berikut:

\section{Pengujian Hipotesis Pengaruh Promosi Daerah Terhadap Keputusan berkunjung wisatawan}

Dari tabel 2, Hasil perhitungan yang telah dilakukan diperoleh nilai t hitung untuk promosi daerah sebesar 2,175 dengan nilai signifikansi sebesar 0,032 sedangkan melalui level of significance (taraf signifikansi) sebesar 0,05. Responden dalam penelitian ini sebanyak 85 orang, maka derajat kebebasan (df) adalah n-k-l = 
Raja Ela Safitri, dkk.: Promosi Daerah dan E-Marketing...

82 adalah 2000, sehingga t hitung > tabel, dan nilai probabilitas lebih kecil dari 0.05 . Dengan hasil tersebut dapat ditarik kesimpulan bahwa pengujian tersebut menunjukkan pengaruh yang siginifikan antara promosi daerah terhadap keputusan berkunjung wisatawan di Yogyakarta. Penjelasan tersebut dapat dtarik kesimpulan bahwa meningkatnya promosi daerah dapat meningkatkan Keputusan Berkunjung Wisatawan di Yogyakarta.

\section{Pengujian Hipotesis Pengaruh Promosi Berbasis E-marketing terhadap Keputusan Berkunjung Wisatawan}

Dari tabel 2, hasil perhitungan yang telah dilakukan, maka diperoleh t hitung untuk variabel interaksi E-marketing adalah sebesar 8,827 dengan hasil signifikansinya 0,000 sedangkan melalui level of significance (taraf signifikansi) sebesar 0,05. Responden dalam penelitian ini sebanyak 85 orang, maka derajat kebebasan (df) adalah n-k-1 = 82 adalah 2,000, Sehingga t-hitung $>$ ttabel, dan nilai probabilitas lebih kecil dari 0,05. Dengan demikian terdapat pengaruh yang signifikan antara Emarketing terhadap Keputusan Berkunjung Wisatawan di Yogyakarta dengan Promosi Daerah sebagai variabel kontrol. Dengan hasil tersebut dapat disimpulkan bahwa pengujian tersebut menunjukkan pengaruh yang signifikan antara Emarketing terhadap Keputusan Berkunjung Wisatawan di Yogyakarta dengan Promosi Daerah sebagai variabel kontrol. Penjelasan tersebut dapat ditarik kesimpulan bahwa meningkatnya E-marketing dapat meningkatkan Keputusan Berkunjung Wisatawan di Yogyakarta.

\section{KESIMPULAN}

Hasil pengujian dengan menggunakan regresi linier berganda menunjukkan bahwa pengaruh Promosi Pariwisata Halal Berbasis E-Marketing Terhadap Keputusan Berkunjung Wisatawan di Yogyakarta dapat meningkatkan minat wisatawan yang awalnya ketika menggunakan promosi daerah hanya memperoleh sebesar 3\% dan ketika menggunakian E-Marketing meningkat menjadi 69\%. Berdasarkan hasil penelitian tersebut menunjukkan bahwa penggunaan promosi E- 
Marketing efektif untuk meningkatkan minat wisatawan untuk berkunjung ke pariwisata halal di Yogyakarta.

Berdasarkan hasil penelitian, kami merekomendasikan pihak Dinas pariwisata Yogyakarta untuk meningkatkan lagi penggunaan E-Marketing untuk memasarkan pariwisata halal di Yogyakarta. Pemerintah daerah juga dapat mengembangkan starup untuk mengembangkan E-Marketing yang ada saat ini. Saran dan rekomendasi untuk peneliti selanjutnya agar mengikutsertakan variabel-variabel yang dianggap dapat mempengaruhi keputusan wisatawan untuk berkunjung di pariwisata halal. Menambah sampel penelitian dan memperluas popolasi yang akan diteliti, agar peneliti juga melakukan Uji asumsi klasik yang lebih lengkap untuk memperoleh hasil yang lebih maksimal dalam menggambarkan output penelitian.

\section{DAFTAR PUSTAKA}

Alim, H. T., Riansyah, A. O., Hidayah, K., Muslimin, I., \& Adityawarman, A. (2015). Analisis potensi pariwisata syariah dengan mengoptimalkan industri kreatif di Jawa Tengah dan Yogyakarta. PKM-P didanai DIKTI, 1-10.

Aribowo, B. Koinikasi Pemasaran Iklan-Iklan Syari'ah.

Badan Pusat Statistik Jakarta Pusat, 2010.Pedoman Pendataan Survei Jumlah Penduduk Muslim Indonesia Tahun 2010. Jakarta Pusat: Badan Pusat Statistik.

Chookaew, S., Chanin, O., Charatarawat, J., Sripraset, P., \& Nimpaya, S. (2015). Increasing Halal Tourism Potential at Andman Gulf in. Journal of Economics, Business and Management, III (7), 277-279.

Ghozali, I. (2006). Aplikasi analisis multivariate dengan program SPSS. Badan Penerbit Universitas Diponegoro.

Imanuel, O. J. Analisis Keputusan Pembelian Konsumen melalui Media Online (EMarketing). Jurnal Ekonomi Universitas Esa Unggul, 4(2).

J. Paul Peter, Jerry C. Olson (2000). Perilaku Konsumen dan Strategi Pemasaran. Edisi ke-empat. jilid 1. Jakarta: Erlangga. 
Raja Ela Safitri, dkk.: Promosi Daerah dan E-Marketing...

Kalyanam, K., \& McIntyre, S. (2002). The e-marketing mix: a contribution of the etailing wars. Journal of the academy of marketing science, 30(4), 487-499.

Kotler, N. G., Kotler, P., \& Kotler, W. I. (2008). Museum marketing and strategy: designing missions, building audiences, generating revenue and resources. John Wiley \& Sons.

Lina Munirah, K., \& Hairul Nizam, I. (2012). Muslim Tourists. In Typology in Malaysia: Perspectives and Challenges'-Proceedings of the Tourism and Hospitality International Conference (THIC 2012).

Nugraha, Y. M. (2018). Analisis Potensi Pariwisata Halal di Kepulauan Riau. Penelitian dan Karya Ilmiah, 3(2), 63-68.

Rahmanto, D., \& Nasrullah, N. (2019). Risiko dan peraturan: fintech untuk sistem $\begin{array}{llll}\text { stabilitas } & \text { keuangan. } & \text { INOVASI, } & \text { 44-52. }\end{array}$ doi:http://dx.doi.org/10.29264/jinv.v15i1.4339

Sofyan, R. (2012). Prospek Bisnis Pariwisata Syari'ah. Jakarta: Republika.

Tandusan, C. F. (2015). Analisis Komparasi Efektivitas Penjualan Sebelum Dan Sesudah Menggunakan Video Marketing Online Talk Fusion Di Manado. Jurnal Riset Bisnis dan Manajemen, 3(2).

Yousaf, S., \& Xiucheng, F. (2018). Halal culinary and tourism marketing strategies on government websites: A preliminary analysis. Tourism Management, 68, 423443. 
Islamiconomic: Jurnal Ekonomi Islam Vol.10 No.1 Januari - Juni 2019 